\title{
Experiential Learning through Field Trips: Effects on Educational, Social and Personal Development among Linguistics Majors
}

\author{
Yvonne M. Campbell* \& Remmy Gedat
}

Faculty of Language and Communication, Universiti Malaysia Sarawak, Sarawak, Malaysia.

\begin{abstract}
The study explores a group of university students' perceptions towards field trips and the effect on their educational, social, and personal development. Data was collected using questionnaires and it has revealed that participants' overall perception of field trips was positive. Findings showed that participants preferred certain aspects of the field trips, particularly those on gaining new experiences and the opportunity to apply what they have learned. It helped improve their knowledge, interest, confidence, communication skills, social training, and awareness of the world around them. However, the least liked aspects were the pre-and post- activities, group size and time allocation. Future studies may want to examine and compare a more varied sampling of students from various fields and perceptions of different genders.
\end{abstract}

Keywords: field trips, experiential learning, perception, awareness, motivation

ARTICLE INFO

Email address: mvyvonne@unimas.my (Yvonne M. Campbell)

*Corresponding author

https://doi.org/10.33736/jcshd.3430.2021

e-ISSN: 2550.1623

Manuscript received: 8 May 2021; Accepted: 13 September 2021; Date of publication: 25 September 2021

Copyright: This is an open-access article distributed under the terms of the CC-BY-NC-SA (Creative Commons Attribution-NonCommercial-ShareAlike 4.0 International License), which permits unrestricted use, distribution, and reproduction in any medium, for non-commercial purposes, provided the original work of the author(s) is properly cited. 


\section{INTRODUCTION}

Field trips are one of the many ways students can experience and apply what they have learned in the classroom in real-life contexts. Numerous studies conducted on the effectiveness of field trips in enhancing the learning experience and development showed that students remember more what they had learned in the classroom when they participated in field trips (Behrendt \& Franklin, 2014; Bowen, 2014; Kennedy, 2014; Krakowka, 2012; Mahgoub \& Alawad, 2014; Manner, 2018; Myers $\&$ Jones, 2004). Field trips have been used as part of the teaching and learning process in many fields, including arts (Mahgoub \& Alawad, 2014), geography (Ilovan, Dulama, Nagy \& Adorean, 2019; Krakowka, 2012; Latipah, Ruhimat \& Somantri, 2019; Preston, 2016), science (Behrendt \& Franklin, 2014), engineering (Hanh \& Hop, 2018; Seifan, Dada \& Berenjian, 2020) and even law (Higgins, Dewhurst \& Watkins, 2012; Nawi \& Fuziana, 2016).

Field trips are organised education excursions or outings to a pre-determined place or setting (Higgins, Dewhurst \& Watkins, 2012). Mahgoub and Alawad (2014) described that field trips expose students to real-life situations and contexts, which help enhance the students' level of knowledge and understanding of a particular subject. Field trips may range from half a day to a weekend (Higgins, Dewhurst \& Watkins, 2012).

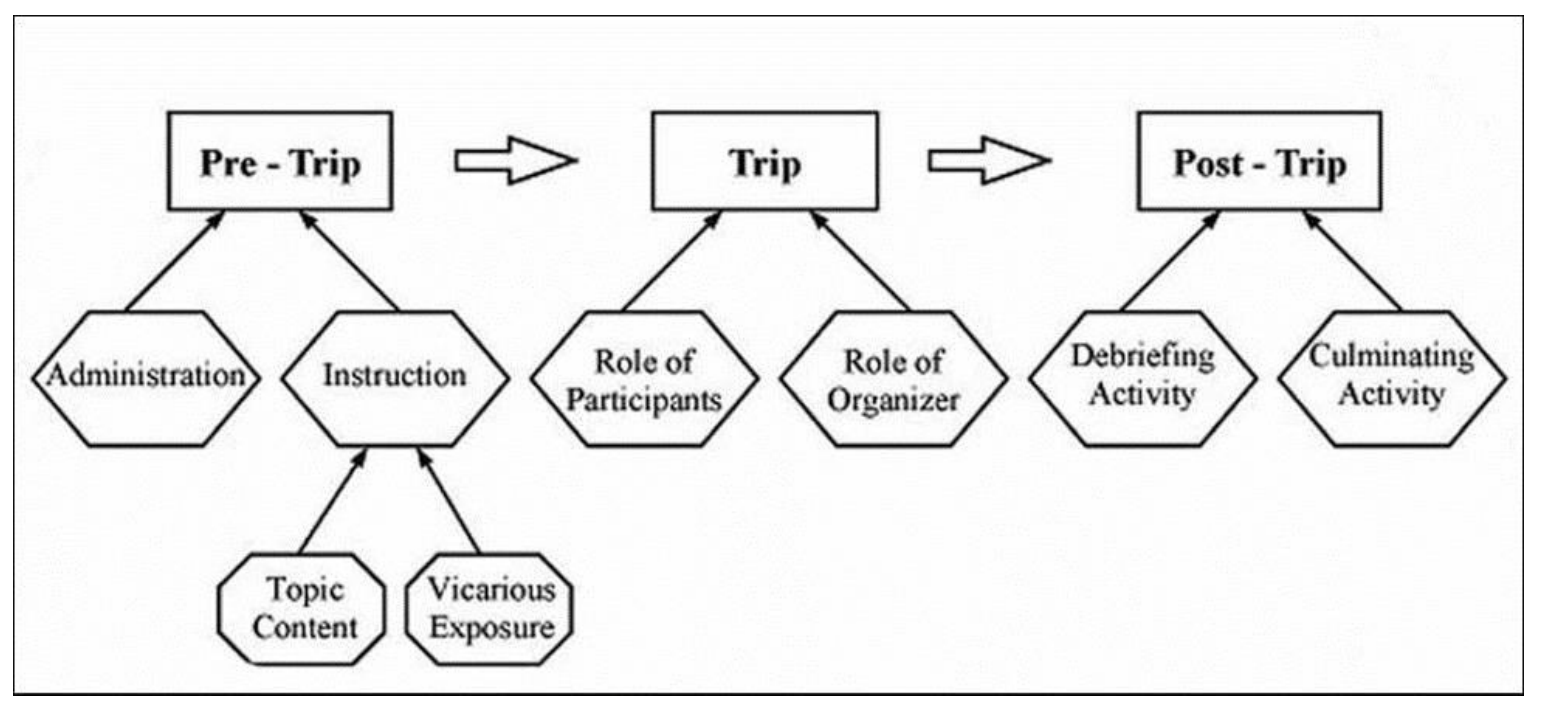

Figure 1. Myers \& Jones' (2004) Field trip model

(Source: https://edis.ifas.ufl.edu/publication/wc054)

According to Myers and Jones (2004), a carefully planned field trip can enhance students' educational experience by giving first-hand knowledge and unique learning opportunities on a particular subject or concept. However, Myers and Jones (2004) stated that the field trips need to be appropriately designed and planned for students to reap their benefits and meet their objectives. They proposed the model below in organising a successful field trip. 
The pre-trip stage involves the administration and instruction components. The administration component includes arranging logistics such as obtaining permission from various parties involved, transportation, determining the location and scheduling the activities. On the other hand, the instruction component includes preparing the students for the trips, such as conducting research before the trip to reduce anxiety and preparing for the unknown. This component also includes an explanation of safety measures, use of the equipment and any item related to the trip, and group division and role of members. The second stage, or trip stage, involves the roles of the participants and organisers. The roles of participants include understanding the planned agenda and the rules and regulations related to the trip.

In contrast, the roles of the organisers involve the instructors as facilitators to observe, interact and guide the students. The final stage, which is the post-trip stage, involves debriefing. Students would share and discuss their experience, what they have discovered and learned. In the culminating activity, students would apply what they have learned during the field trip and connecting what they have learned in the classroom with the real-life experience in the field trip.

Numerous studies have shown that field trips enhance all three learning domains - cognitive, affective, and psychomotor (DeWitt \& Storksdieck, 2008; Meezan \& Cuffey, 2015; Powers, 2004; Radke, 2016; Rickinson et al., 2004; Stokes \& Boyle, 2009). However, due to the many constraints, including financial, time-consuming, the many procedures and red tapes involved as well as safety reasons which make it challenging to conduct, there has been a lack of inclusion of field trips, even at the university level (Myers \& Jones, 2004).

In higher learning education, the importance of balancing theory and practice is fundamental in ensuring that students develop holistically (Arcodia, Novais, Cavlek \& Humpe, 2021). Thus, it is essential to comprehend the effects of field trips on students and their perceptions of these field trips. This study, therefore, seeks to explore the educational experience of field trips by focusing on the students' perceptions of this teaching and learning method, especially among university students and how they think the field trip has helped them in learning and, most importantly, in life. In addition, it also aimed to analyse how helpful field trips are in helping the students develop and motivate themselves.

\section{FIELD TRIPS AND LEARNING}

A field trip is often associated with experiential learning, 'authentic, first-hand, sensory-based learning' (Behrendt \& Franklin, 2014, p. 237). In experiential learning, students experience firsthand the things they were taught in the classroom - explore, touch, listen, watch and the likes. According to The Association for Experiential Education (2012), in experiential learning, students are directed by the instructor to a specific experience, and then guide the students through reflection to "increase knowledge, develop skills, clarify values, and develop people's capacity to contribute to their communities" '(Behrendt \& Franklin, 2014, p. 237).

According to Kolb (1983), experiential learning is a circular process. Students start with an experience, then reflect on that experience and abstraction as they think of that experience and 
active experimentation whereby, they plan or try out what they have learned. It can also include a new idea, test, or concept. Each time the cycle is completed, some forms of learning have occurred.

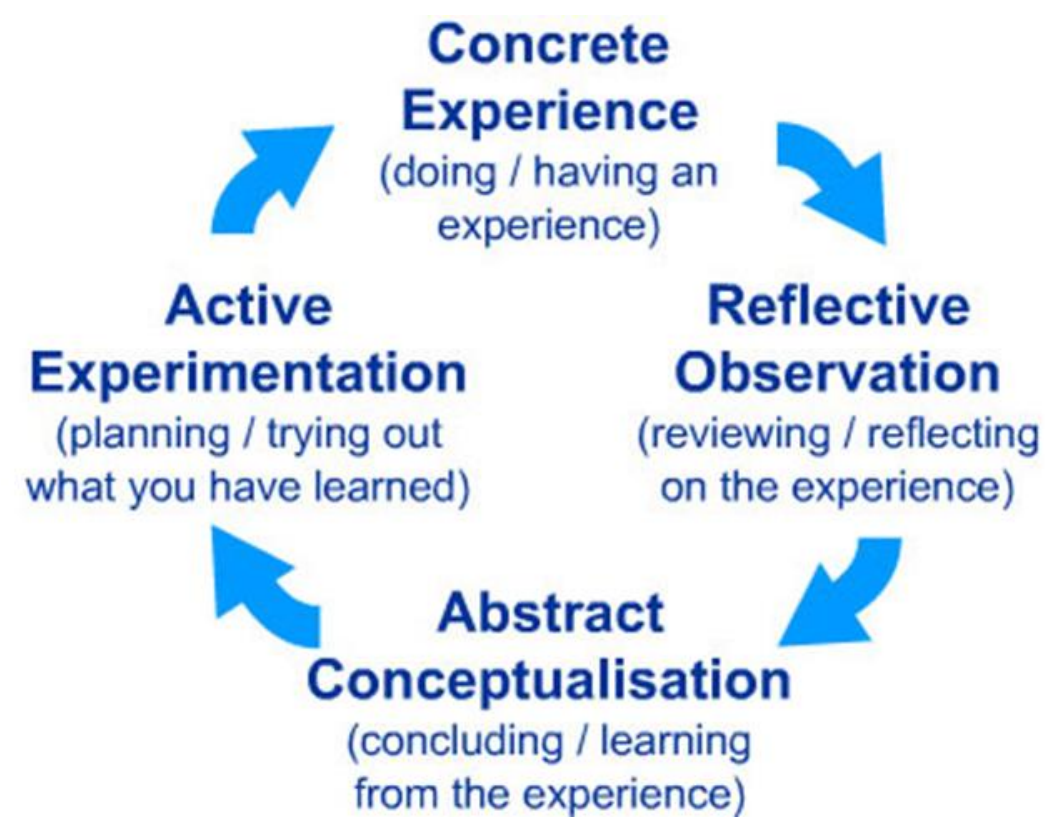

Figure 2. Kolb's (1983) Experiential Learning (Source: from https://www.simplypsychology.org/learning-kolb.html)

Experiential learning also acknowledges the existence and integration of prior knowledge of the students. It is believed that those with more prior knowledge would make connections to the subject matter better (Kisiel, 2006). Field trips provide experiential learning by giving the students opportunities to experience for themselves the subject matters in which they have only heard of in the classroom and, to a certain extent, apply what they have learned.

\section{METHODOLOGY}

This study employed both qualitative and quantitative approaches. It was participated by 41 students who enrolled for the Introduction to Linguistic Anthropology course offered in the B.A. Linguistics programme. These students were 2nd-year students and have gone through some introductory courses in Linguistics such as Phonetics and Phonology, Morphology, Syntax, Semantics and Pragmatics.

The students were first exposed to the theories, concepts, and research methodology used in Linguistic Anthropology. They then participated in an organised field trip, where they collected data for an assigned research task in a local community. The chosen community is Kampung Sebuyau Ensengei Iban, an Iban longhouse located about $89 \mathrm{~km}$ from Kota Samarahan, Sarawak. The trip was a one-day trip whereby the journey there was by bus. However, the students and instructors had to walk the final $2 \mathrm{~km}$ to reach their destination. Before the actual day of the field 
trip, the students were divided into six to seven members. Each group was assigned a specific topic related to Language and Culture, such as traditional food, dances, music, rituals, and oral traditions. They had to brainstorm questions and conduct research related to their respective topics. The students also had to ensure that they had the correct equipment needed for their field trips to collect data, such as an audio recorder, video recorder and mini microphones supplied by the instructor. During the field trip, the students were required to collect data using ethnographic methods taught in the classroom, such as interviews, observations, and field notetaking. Before the students went out to conduct their data collection, a small ice-breaking session with the villagers was carried out, and it consisted of speech from the village Headman and getting to know the longhouse and villagers. The students, in their groups, were then allowed to move around the longhouse. They socialise with the villagers while collecting data through interviews and observations. After the field trip, the students needed to carry out post-trip activities, which included writing a self-reflection essay, a report of their study, the data collected and the analysis, and produce an E-book related to the village and the culture and language of the people. It is part of their community project in which they were required to give back to the community, especially in terms of language and culture.

The instrument used in this study was a questionnaire that consisted of a four-point Likert scale with questions on the students' opinions and perceptions of the field trip. These questions centred around the notion of better understanding, awareness, confidence, social and communication skills.

\section{RESULT AND DISCUSSION}

The data was tabulated to generate the percentage value to determine the degree of agreement for each item. Most participants in this study have been on field trips in the other courses, including their co-curricular and college activities, even before enrolling in this Introduction to Linguistic Anthropology course. Figure 3 shows the number of times the students have been on field trips. Based on their responses, the students have experienced field trips before joining this field trip for their Introduction to Linguistic Anthropology course. 24\% of the students have been on at least one trip. Another $29 \%$ have been on two trips, and $20 \%$ have been on three. $12 \%$ have joined field trips four and five times each, and only $2 \%$ have been to five field trips. It shows that most of the students were not new to the experience of going on field trips. 


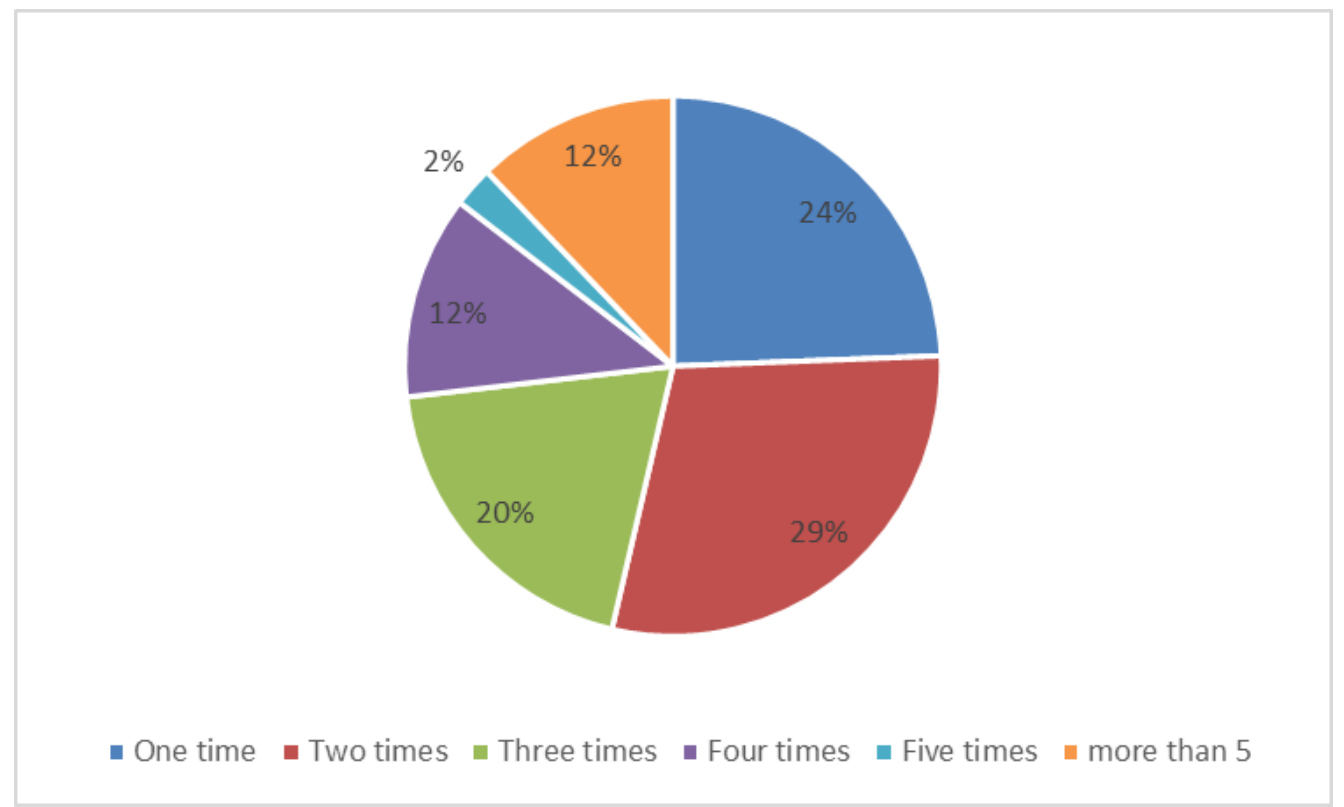

Figure 3. Number of times students have been on field trips

The participants were then asked which aspects of the field trips they liked. Their responses are summarised in Table 1 below:

Table 1. Aspects liked in the field trip

\begin{tabular}{|ccc}
\hline Items & $\begin{array}{c}\text { No of } \\
\text { responses }\end{array}$ & $\begin{array}{c}\text { Percentage (Likert scale 4 } \\
\text { 'strongly agree' \& 3 'agree') }\end{array}$ \\
\hline Getting experience & 41 & $100 \%$ \\
\hline Activities on trip & 41 & $100 \%$ \\
\hline Transportation and journey & 32 & $78 \%$ \\
Clear objectives & 31 & $76 \%$ \\
\hline Apply techniques learned in class & 29 & $71 \%$ \\
Meal & 28 & $68 \%$ \\
\hline Instructors' involvement & 27 & $66 \%$ \\
Length of time & 19 & $46 \%$ \\
Organisation of trip & 19 & $46 \%$ \\
\hline Information prior to the trip & 19 & $46 \%$ \\
Group size & 18 & $44 \%$ \\
\hline Pre and post-field trip activities & 16 & $39 \%$ \\
\hline
\end{tabular}

Table 1 above shows that all participants liked that they were gaining experience from the trip. They also liked the activities conducted during the trip, which involved meeting the community members, communicating, and interacting with them, and experiencing the communal life of the longhouse community. The least liked aspect of the trip was the pre-and post-field trip activities 
which involved researching the trip. It is a requirement of the course and an organised field trip whereby students need to research the community they will be visiting (Myers \& Jones, 2004). In the same study, Myers and Jones (2004) stipulated that having some form of information before a trip is crucial. Students need to have an idea of what they will be facing and familiarise themselves with the community they will visit. It will also prepare them culturally, mentally, physically, and emotionally for what is to come.

Interestingly, only $46 \%$ stated that they liked the information given by the instructor prior to the trip, while the remaining did not like it. It may well indicate that the students expect the instructor to provide all information rather than research. The post-trip activities involved writing a selfreflection essay, report and producing an E-book based on the data collected during the field trip. Although the participants enjoyed the trip and the experience, they did not enjoy the extra work required after the trip.

The participants also indicated that they did not like the group size and the length of time of the field trip. The field trip was only a day, so the participants may feel that they did not have enough time to interact with the people and collect sufficient data. In terms of the group size, they may feel that the group was too big and difficult to manage. However, the participants were divided into smaller groups of six to seven members.

In terms of the other aspects, more than $50 \%$ of the participants noted that they liked the transportation and journey, the clear objective of the trip, and the chance to apply what they have learned in the classroom in the real world. It is crucial because the whole purpose of the trip was to expose students to the community aspects of Linguistic Anthropology and the ability to use their knowledge and skills in real life. The students were also happy with the meal provided and the instructors' involvement in the whole trip, including supporting and helping the students. At the same time, they carried out their data collection activities.

The participants were also asked their general opinions on the field trip. They reported that they were happy with the trip, as reflected in Table 2 below:

Table 2. General opinions of the fieldwork

\begin{tabular}{|c|c|c|c|c|}
\hline & SA & $\mathbf{A}$ & D & SD \\
\hline $\begin{array}{l}\text { The field trip was well integrated with the lessons learned in the } \\
\text { classroom }\end{array}$ & $27 \%$ & $71 \%$ & $2 \%$ & $0 \%$ \\
\hline Field trips must be compulsory in the linguistic classroom & $32 \%$ & $59 \%$ & $10 \%$ & $0 \%$ \\
\hline Field trips should be made compulsory in all subjects & $27 \%$ & $39 \%$ & $29 \%$ & $5 \%$ \\
\hline Field trips should be made voluntary in all subjects & $29 \%$ & $54 \%$ & $15 \%$ & $2 \%$ \\
\hline Field trips should be organised by lecturers & $27 \%$ & $59 \%$ & $15 \%$ & $0 \%$ \\
\hline Field trips should be organised by students & $18 \%$ & $60 \%$ & $20 \%$ & $3 \%$ \\
\hline $\begin{array}{l}\text { Lecturers should give an opportunity to students to organise field } \\
\text { trips. }\end{array}$ & $22 \%$ & $68 \%$ & $10 \%$ & $0 \%$ \\
\hline
\end{tabular}


Students should get more chance to learn more information from $\quad 41 \% \quad 59 \% \quad 0 \% \quad 0 \%$ teachers

\begin{tabular}{lllll}
\hline Teachers should ask students to prepare a report after field trips & $28 \%$ & $59 \%$ & $13 \%$ & $0 \%$
\end{tabular}

Table 2 above shows that $98 \%$ of the participants felt that the field trip was well integrated with the lessons taught in the classroom. The majority (90\%) agreed that field trips should be made compulsory in the linguistics classroom. $66 \%$ agreed for it to be included in all their other subjects. Another $10 \%$ felt that it should not be made compulsory in linguistics. However, 34\% disagreed that a field trip to be incorporated into their other subjects. $83 \%$ of the participants felt that field trips should be made voluntary instead.

Most participants also reported that they felt that these field trips should be organised by lecturers and students, 59\% and 60\% respectively. They felt that lecturers should allow the students to help organise these trips (68\%) and that students should be given more chances to get information from their lecturers before the trip (100\%). It coincided with the result from questions related to aspects the student enjoyed most about the trip, whereby $54 \%$ stated they would like more information from the instructors before the trip. $87 \%$ felt that students should prepare a report after the field trip.

\subsection{Perceptions and Attitudes}

The next part of the questionnaire focused on the students' perceptions and attitudes towards the field trip. The analysis divides the questions into better understanding, awareness, confidence, social and communication skills.

Table 3. Students' perceptions towards the field trip

\begin{tabular}{lllll} 
& SA & A & D & SD \\
\hline Was an important experience for me & $63 \%$ & $37 \%$ & $0 \%$ & $0 \%$ \\
\hline Provided opportunity to show individualities & $37 \%$ & $54 \%$ & $10 \%$ & $0 \%$ \\
\hline Helpful for an individual to show better performance in studies & $34 \%$ & $59 \%$ & $10 \%$ & $0 \%$ \\
\hline Provide self-experience and observation to increase knowledge & $56 \%$ & $44 \%$ & $0 \%$ & $0 \%$ \\
\hline
\end{tabular}

The students indicated positive perceptions towards the field trip. They felt that the trip was an essential experience for them and helped provided opportunities for them to show their individualities. The trip also helped to provide them with experiences and helped increase their knowledge.

\subsection{Interest and Understanding}

When asked how the field trip may have influenced their interest and understanding in learning and Linguistic Anthropology, the participants perceived that it has managed to create interest in learning among the students. Table 4 below reflects how the participants felt about the field trip connected with their interest in learning. 
Table 4. Field trip and interest in learning

\begin{tabular}{lllll} 
& SA & A & D & SD \\
\hline Developed more interest in learning & $41 \%$ & $56 \%$ & $2 \%$ & $0 \%$ \\
\hline Helped increase knowledge & $56 \%$ & $44 \%$ & $0 \%$ & $0 \%$ \\
\hline Helped improved my knowledge & $68 \%$ & $32 \%$ & $0 \%$ & $0 \%$ \\
\hline Had me excited about language, linguistics and culture & $56 \%$ & $44 \%$ & $0 \%$ & $0 \%$ \\
\hline $\begin{array}{l}\text { Made linguistics more real for me because I was more } \\
\text { involved. }\end{array}$ & $46 \%$ & $49 \%$ & $5 \%$ & $0 \%$ \\
\hline
\end{tabular}

The students claimed that the field trip has made them excited about the subject matter, which was language, linguistic and culture. $98 \%$ of the students claimed that the field trip has developed more interest in learning and made linguistics more natural for them since they were more involved. They also felt that the field trip helped increased their knowledge. It may well indicate that the field trip has created more interest in the students and interest in the subject and the course.

Students' understanding of subject matter. It has led to another aspect about whether the field trip helped the students understand the subject better. The students' responses are reflected in Table 5 below:

Table 5. Students' responses

\begin{tabular}{|c|c|c|c|c|}
\hline & SA & $\mathbf{A}$ & $\mathbf{D}$ & SD \\
\hline Helped me understand the relevance of my curriculum & $38 \%$ & $55 \%$ & $10 \%$ & $0 \%$ \\
\hline $\begin{array}{l}\text { Helped me understand how to apply linguistic methods and ask } \\
\text { linguistic-based questions }\end{array}$ & $37 \%$ & $55 \%$ & $5 \%$ & $0 \%$ \\
\hline $\begin{array}{l}\text { It helped me understand how to apply my skills and knowledge } \\
\text { to a 'real-life situation. }\end{array}$ & $39 \%$ & $61 \%$ & $0 \%$ & $0 \%$ \\
\hline Helped me to understand the subject matter better & $46 \%$ & $51 \%$ & $2 \%$ & $0 \%$ \\
\hline $\begin{array}{l}\text { Helped me gain important skills and understand linguistics and } \\
\text { the research process }\end{array}$ & $49 \%$ & $46 \%$ & $5 \%$ & $0 \%$ \\
\hline
\end{tabular}

First, the field trip has helped the participants understand the relevance of their curriculum, including the need to do applied linguistics analysis such as semantics and pragmatics, and gave a practical approach to the curriculum (95\%). The field trip has also enhanced the students understanding of the subject by helping them understand how to apply their skills and knowledge to a real-life situation. At the same time, $95 \%$ of the students claimed that the field trip has also helped them gain essential skills and understand the linguistic and research process. It indicates that students could see the 'big picture of what encompasses linguistics, especially Linguistic Anthropology and how it relates to a real-life situation through this field trip. Given the opportunity to apply what they have learned in the classroom, they could utilise these skills and gain new skills and knowledge. Overall, $98 \%$ of the students felt that the field trip had helped them understand the subject material better. 


\subsection{Levels of Confidence}

Another important aspect which was taken into consideration was the confidence levels of the students. Table 6 reflects the answers related to the participants' confidence and how the field trip may have affected their confidence levels.

Table 6. Confidence levels about the field trip

\begin{tabular}{lllll}
\hline & SA & A & D & SD \\
\hline Gained confidence & $41 \%$ & $49 \%$ & $10 \%$ & $0 \%$ \\
\hline Increased self-confidence & $54 \%$ & $39 \%$ & $5 \%$ & $0 \%$ \\
\hline Gained confidence to do linguistics research & $44 \%$ & $51 \%$ & $2 \%$ & $2 \%$ \\
\hline Helped me achieve better results & $30 \%$ & $53 \%$ & $18 \%$ & $0 \%$ \\
\hline Helpful to meet the needs of higher education & $32 \%$ & $59 \%$ & $10 \%$ & $0 \%$ \\
\hline
\end{tabular}

In this aspect, the participants claimed that the field trip helped them gain confidence (90\%) and increased their confidence (93\%). It has also helped them gain confidence in their ability to conduct linguistic research, and they felt that field trips helped them achieve better results $(82 \%)$ and meet the needs of higher education and skills $(90 \%)$.

\subsection{Students' Communication Skills and Social Training}

The field trip has also helped the participants with their communication skills and social training. It can be seen in their self-evaluation Table 7 below:

Table 7. Communication skills and social training

\begin{tabular}{lllll} 
& SA & A & D & SD \\
Helpful in social training & $51 \%$ & $49 \%$ & $0 \%$ & $0 \%$ \\
\hline Promoted interaction between students and lecturers & $61 \%$ & $37 \%$ & $2 \%$ & $0 \%$ \\
\hline Promoted cooperation and unity among student & $53 \%$ & $45 \%$ & $3 \%$ & $0 \%$ \\
\hline Helped promote a sense of discipline & $46 \%$ & $49 \%$ & 55 & $0 \%$ \\
\hline Developed leadership qualities & $45 \%$ & $55 \%$ & $0 \%$ & $0 \%$ \\
\hline
\end{tabular}

The participants have claimed that the field trip helped with their social training, whereby it helped promote interactions among themselves (97\%) and their lecturers (98\%) as well as promote cooperation and unity among themselves (98\%). The trip also helped improve their inner qualities, including developing leadership quality (100\%) and promoting a sense of discipline within themselves $(95 \%)$.

\subsection{Awareness Level}

In terms of creating awareness, the aspects considered are professional skills, societal awareness, and future awareness. Table 8 summarises the awareness aspects of the students. 
Table 8. Awareness levels of Professional Skills, Society and Future

\begin{tabular}{|c|c|c|c|c|}
\hline & SA & $\mathbf{A}$ & D & SD \\
\hline Helped me to be aware of my professional skills & $37 \%$ & $56 \%$ & $7 \%$ & $0 \%$ \\
\hline Helped me be aware of the facilities available within society & $32 \%$ & $61 \%$ & $7 \%$ & $0 \%$ \\
\hline $\begin{array}{l}\text { Helped promoted the importance of historical places and cultural } \\
\text { heritage }\end{array}$ & $51 \%$ & $46 \%$ & $2 \%$ & $0 \%$ \\
\hline helped me to guide to face future challenges and hindrances & $45 \%$ & $53 \%$ & $3 \%$ & $0 \%$ \\
\hline experience on the trip would help my future career & $44 \%$ & $46 \%$ & $10 \%$ & $0 \%$ \\
\hline helped me to understand their career options & $39 \%$ & $46 \%$ & $12 \%$ & $2 \%$ \\
\hline Helped me think about the future and what I want to do & $27 \%$ & $59 \%$ & $12 \%$ & $2 \%$ \\
\hline $\begin{array}{l}\text { Helped me realise that real linguistics is full of surprises, and a } \\
\text { planned study may not go as planned }\end{array}$ & $48 \%$ & $45 \&$ & $8 \%$ & $0 \%$ \\
\hline $\begin{array}{l}\text { Helped me realise that data are not always what you think or hope } \\
\text { in planning a study }\end{array}$ & $54 \%$ & $44 \%$ & $2 \%$ & $0 \%$ \\
\hline
\end{tabular}

The field trip has helped participants to be aware of their professional skills (93\%). It also made the students aware of the facilities available within their society (93\%). The students felt that the field trip promoted the importance of historical places and cultural heritage (98\%). The students also felt that the field trip helped guide them to face future challenges and hindrances (97\%). They believed that their experience on the trip would help their future career (90\%). The trip helped them to understand their career options (85\%). However, $15 \%$ felt that the trip did not help them understand their career options. 86\% stated that the trip helped them think about their future and what they wanted to do, while $14 \%$ disagreed. The trip prepared them for challenges, and it made them realise that sometimes, things they planned might not go as planned (92\%). The trip helped them realise that data are not always what they think or hope when planning a study $(98 \%)$.

\section{CONCLUSION}

The Linguistics majors who have participated in the study were optimistic about the whole experience of the field trip. The most liked aspects of the field trip are getting new experiences, the activities during the field trip, the journey itself, and the ability to apply what they have learned in the classroom. However, some of the least-liked aspects were the time length, which may be too short, and the group size, which may be too big. Another least liked aspect was the pre-and postactivities, which included researching the trip to understand better the community they were about to research. It is, however, a crucial part of the field trip. In this case, they need to conduct a more extensive reading on the community they are about to study. The students also stated that they would like more information from the instructor, but that would defeat carrying out a field trip.

Although most participants enjoyed the trip, not all felt it should be compulsory for the linguistic classroom and other subjects. They also felt that lecturers and students should be allowed to organise these field trips together to create more exposure to the students. 
The participants also felt that the field trip improved their knowledge and increased their interest in learning. It could be because they had the chance to apply and experience what they have learned in the classroom in the real world.

The field trip also increased their confidence in themselves and to carry out research and interact with the community. It helped, in a way, with their communication skills and social training where they had to work together, interact with one another and the community members, and gave them a sense of discipline and leadership quality. The field trip also created awareness among the students regarding their social lives, professional lives, and future. The field trips made students more aware of facilities within society and helped them.

This survey revealed that field trip is beneficial to these Linguistics majors, in several ways, such as increasing their confidence, learning interest and knowledge, communication skills, and awareness of the world around them.

Many studies on field trips revealed that students benefit significantly from these trips since they are exposed to the 'real world' and experience things that they only hear and see in the classroom. This study, although small in sampling, also revealed the benefits as perceived by the students. They felt optimistic about these trips because they gained experience and knowledge and broke away from the monotonous setting of the traditional classroom.

Future studies may want to explore the perceptions of a more varied sampling from the sciences, humanities, and arts. It would also be interesting to find out if gender affects the perceptions of the students as well.

\section{ACKNOWLEDGEMENTS}

This work was funded by the Scholarship of Teaching and Learning Grants (SoTL), Universiti Malaysia Sarawak, Grant no: SOTL/FBK/2018(1)/007.

\section{REFERENCES}

Arcodia, C., Novais, M.A., Cavlek, N., \& Humpe, A. (2021). Educational tourism and experiential learning: students' perceptions of field trips. Tourism Review, 76(1), 241-254. doi: 10.1108/tr-052019-0155

Behrendt, M., \& Franklin, T. (2014). A review of research on field trips and their value in education. International Journal of Environmental and Science Education, 9 (3), 235-345. doi: 10.12973/ijese.2014.213a

Bowen, D.H. (2014). The educational value of field trips. Education Next, 14(1), 78-86. Retrieved from https://www.researchgate.net/publication/289374487_The_Educational_Value_of_Field_ Trips 
DeWitt, J., \& Storksdieck, M. (2008). A short review of school field trips: Key findings from the past and implications for the future. Visitor Studies, 11(2), 181-197. doi:10.1080/10645570802355562

Hanh, N.V., \& Hop, N.H. (2018). The effectiveness of the industrial field trip in Introduction to Engineering: A case study at Hung Yen University of Technology and Education, Vietnam. International Journal of Electrical Engineering Education, 55(3), doi: $10.1177 / 0020720918773050$

Higgins, N., Dewhurst, E., \& Watkins, L. (2012). Field trips as short-term experiential learning activities in legal education. The Law Teacher, 46 (2), 165-178. doi: $10.1080 / 03069400.2012 .681231$

Ilovan, O.R., Dulama, E.M., Nagi, K.X.H., \& Adorean, C. (2019). Geographical field trips during university studies. Whereto? (II). Romanian Review of Geographical Education, 8(1), 5-23. doi: 10.23741/RRGE120191

Kennedy, M. D. (2014). The benefit of field trips. University Honors Program Theses. Georgia Southern University. Retrieved from https://digitalcommons.georgiasouthern.edu/honorstheses/60

Kisiel, J. (2006). More than lions and tigers and bears-Creating meaningful field trip lessons. Science Activities, 43(2), 7-10. doi: 10.3200/SATS.43.2.7-10

Kolb, D. (1983). Experiential learning, experiences as the source of learning and development. Englewood Cliffs, New Jersey: Prentice-Hall.

Krakowka, A.R. (2012). Field Trips as Valuable Learning Experiences in Geography Courses. Journal of Geography, 111 (6), 236-244. doi:10.1080/00221341.2012.707674

Latipah, M., Ruhimat, M., \& Somantri, L. (2019, June). The Effect of Fieldtrip on Geography of Student's Ecological Intelligence. In IOP Conference Series: Earth and Environmental Science (Vol. 286, No. 1, p. 012009). IOP Publishing.

Mahgoub, Y.M., \& Alawad, A.A. (2014). The impact of field trips on students' creative thinking and practices in Arts education. Journal of American Science, 10(1), 46-50.

Manner, B.M. (2018). Field studies benefit students and teachers. Journal of Geological Education, 43(2), 128-131. doi: 10.5408/0022-1368-43.2.128

Meezan, K.A. L., \& Cuffey, K. (2012). Virtual field trips for introductory Geoscience classes. The California Geographical Society. $\quad$ Retrieved from https://scholarworks.calstate.edu/downloads/0p096b37c 
Myers, B., \& Jones, L. (2004). Effective use of field trips in educational programming: A threestage approach. IFAS Extension, University of Florida. Retrieved from https://edis.ifas.ufl.edu/pdf\%5CWC\%5CWC05400.pdf

Nawi, N.F., \& Fuziana, A. (2016). An assessment of the effectiveness of field trips as a teaching and learning strategy: A case study of a field trip to the Parliament. Journal of Academia UiTM Negeri Sembilan, 4, 1-11.

Powers, A. L. (2004). Evaluation of one- and two-day forestry field programs for elementary school children. Applied Environmental Education and Communication, 3, 39-46. doi: 10.1080/15330150490270622

Preston, L. (2016). Field' work' vs 'feel' trip: approaches to out-of-class experiences in Geography education. Geographical Education, 29, 9-22. Retrieved from https://files.eric.ed.gov/fulltext/EJ1123180.pdf

Radke, A.M. (2016). The value and importance of field trip experience to adult learners in continuing higher education. Retrieved https://minds.wisconsin.edu/bitstream/handle/1793/75579/RadkeAnne.pdf? sequence=5\&isAllow ed $=\mathrm{y}$

Rickinson, M., Dillon, J., Teamey, K., Morris, M., Choi, M. Y., Sanders, D., \& Benefield, P. (2004). A review of research on outdoor learning. Berkshire, UK: National Foundation for Educational Research

Seifan, M., Dada, O.D., \& Berenjian, A. (2020). The effect of real and virtual construction field trips on students' perception and career aspiration. Sustainability, 12(3), 1200-1200. doi: $10.3390 /$ su 12031200

Stokes, A., \& Boyle, A.P. (2009). The undergraduate geosciences fieldwork experience: Influencing factors and implications for learning. In S. J. Whitmeyer, D. W. Mogk, \& E. J. Pyle (Eds) Field Geology Education: Historical Perspectives and Modern Approaches. Geological Society of America Special Paper 461, (pp. 291-311). Geological Society of America. doi: https://doi.org/10.1130/SPE461 